\title{
The North Shore's Forgotten Horse Tramway: The Devonport and Lake Takapuna Tramway Company
}

\author{
DEREK WHALEY
}

\begin{abstract}
One of New Zealand's last horse tramways, the Devonport and Lake Takapuna Tramway Company has been largely neglected by historians, and those who have reported on it often include or imply incorrect information. This has resulted in a universally negative opinion of the tramway that briefly shuttled passengers between Victoria Wharf and Cheltenham Beach in Devonport, Auckland, between 1886 and 1888. This article examines the company's history from the perspectives of those who witnessed its rise and fall, and includes technical details from primary sources, observations by reporters, and additional information derived from photographs, maps, and government documents.
\end{abstract}

The area between Devonport and Lake Pupuke on Auckland's North Shore was experiencing a population boom in the mid-1880s. Isolated from the mainland by Waitemata Harbour and several creeks and rivers, the North Shore developed quickly from the 1860s as a vacation spot for Aucklanders desiring to flee the city and for immigrants seeking a rural life within reach of the city. Devonport was the only true North Shore suburb at the time, and the approximately 2,600 people who lived there wanted all the amenities of Auckland with none of the hassle. ${ }^{1}$

Urban tramways had become a popular mode of transportation throughout Europe and North America in the late 1860s, and the trend spread to New Zealand during the 1870s. The first public tramway opened in 1862 and was a section of the Dun Mountain Railway in Nelson, which otherwise was used for mining. The first purpose-built public tramway, the Foxton Railway, opened in 1871 and soon was speeding passengers forty miles between Foxton and Palmerston North. ${ }^{2}$ On 21 October 1872, the New Zealand government promulgated "An Act to Facilitate the Construction and to Regulate the Working of Tramways," which outlined the legal procedures and requirements for a tramway to operate in the colony. ${ }^{3}$ Soon, trams were operating in Wellington, Auckland, Christchurch, Dunedin, and Invercargill. By 1885, New Zealand had around a dozen urban and interurban tramway companies. ${ }^{4}$ Much of the technical details of tramway operations were left to highway districts and local municipal and regional councils, including bylaws, fares, and track gauges. As a result, those who advocated for tramways and funded them were usually businesspeople and entrepreneurs moonlighting as local politicians, often with close ties to local real estate ventures. They viewed tramways as a means to advertise and promote property, and their interest in the technology only went as far as their potential returns. Thus, they cut corners wherever possible.

The primary way cost cutting was accomplished was through the adoption of horses for motive power. Indeed, this approach worked well for local councils that feared steam locomotives would produce too much noise pollution for their communities. Nearly all of the public tramways in operation before 1900 relied on horsepower. An additional means of ensuring a tram system could be built affordably and quickly was splitting it into sections. Companies could then use the success of one section to attract subscribers for the next. This approach, however, came with the risk that any one section's financial failure could and often did imperil the entire venture. ${ }^{5}$ 


\section{A Tramway on the North Shore}

Devonport was decidedly late to the tramway game. In August 1885, James Knox was hired by a group of Auckland businessmen to survey a tramway network that would crisscross the North Shore on its way north to Lake Pupuke. All the men owned sections on the peninsula, and some, such as Robert Duder, were land agents as well as property investors. They hoped that a tramway would open the North Shore to settlement, but the investors were also hoping for a 15.5 percent per annum return from the line. On 14 August, a provisional board of directors was organised during a meeting at the Masonic Hotel in Devonport. ${ }^{6}$ Five days later, the board elected Graves Aickin as chairman, who then formally announced plans for the incorporation of the Devonport and Lake Takapuna Tramway Company, Ltd., with a capital investment of $£ 10,000$ purchasable in $£ 1$ shares. According to the New Zealand Herald, a "considerable number of shares were subscribed for in the room, and it was understood that a number of gentlemen not present at the meeting had also promised to become shareholders." The paper added optimistically that there was "every prospect of the company being successfully launched."7 Two weeks later, the paper noted that shares were selling well but locals were reluctant to invest. The Herald felt this was short-sighted and suggested that even if the tramway did not pay directly, it would greatly increase the surrounding land's value. ${ }^{8}$

The Auckland Star released an abridged prospectus for the company on 31 August giving many important details. In addition to Aickin, ten prominent local businessmen were appointed directors, and Charles W. Cave was selected secretary pro tempore while also serving as the company's solicitor. Priority was placed on constructing a section between Victoria Wharf (where many of the ferries from Auckland arrived) and Cheltenham Beach (a popular tourist destination and rapidly growing housing subdivision), to tap the summer traffic. ${ }^{9}$ Property developers clearly saw the potential in the line since, within days of the release of the prospectus, they began to include the proposed tramway in their advertising, and continued to do so for the following two years. ${ }^{10}$

As the people behind the tramway company soon learned, planning and implementing did not always go hand-in-hand. On 4 September, Cave petitioned the Devonport Road Board for consent to build the line according to similar terms in use by the Auckland Tramway Company, but the chairman referred the case to the Finance Committee, delaying a decision. ${ }^{11}$ After a month, the board approved the franchise but would not grant the company permit to operate on Sundays, even though the Waitemata County Council imposed no such restriction. ${ }^{12}$ It was a substantial setback, since weekend travel was expected to be one of the primary sources of revenue for the company. The public fear was that Sunday travellers would lead to "an irruption of Auckland larrikins into the quiet suburb of Devonport of a Sunday afternoon" and that the wishes of local ratepayers must be considered. ${ }^{13}$ The issue came to a head on the evening of 26 October at a special Devonport Road Board meeting, when the company announced its decision to relent on the issue before local ratepayers were even given an opportunity to protest. The Star declared the anticipated debate "somewhat of a fizzle." 14 The next day, a letter to the editor sent assurances that "the said deputation in no way represented the ratepayers of Devonport, but only a small section thereof." 15 In reality, the company did not abandon tramway services on Sunday but rather granted the road board the power to decide on a case-by-case basis. Nonetheless, the matter reflected the company's desire to satisfy residents, even if it was potentially swayed by a vocal minority. 
With the matter of tram service on Sundays settled, the company was finally prepared to build the line. On 12 November 1885, the company published in the New Zealand Gazette its formal intent to construct and operate a tramway line within the boundaries of the Devonport Road Board and elsewhere in Waitemata County. The proposed network was divided into five sections, four of which would serve as primary arteries and the fifth as a connection between sections 1 and 3 (Figure 1). The foot of Victoria Wharf would serve as the starting point, with section 1 running down Beach Road (King Edward Parade) and then turning up Cheltenham Road, continuing to the end - a length of one mile. Section 2 would also begin at the wharf and then run up Victoria Road to Lake Road, continuing along Lake Road until splitting at the intersection of The Drive (Hurstmere Road) and Katrine (Anzac) Street in Takapuna, with an eastern segment continuing to Takapuna Beach and a western segment running to Northcote Road. Section 3 would run down Victoria Road to Vauxhall Road, and then turn to end at Narrow Neck Beach. Section 4 would break off from section 2 at Edward Street and continue along Edward and Calliope Road to end at Brick (Stanley) Bay. And section 5 intended to connect section 1 with section 3 via either a track down Lake Street (Tainui Road) or Cheltenham (Oxford) Terrace. ${ }^{16}$ Considered together, the network reflected a bold plan that would have gone a long way towards interconnecting the various tourist hotspots, subdivisions, and communities of the lower North Shore.

\section{The Dream and the Reality}

The same day that the tramway proposal was formally outlined to the public, the Herald reported that the company had "sufficient capital subscribed to construct and equip the first section." It added that "the company have arranged with local manufacturers for the cars for the line, and these are to be ready as soon as the section is ready for traffic." More ominously, though, the newspaper added that the directors "would have liked to have ordered at once the construction of the second section ... had the residents along that line of route assisted more cordially in taking up shares," adding that the issue of Sunday service may have been a stumbling block. ${ }^{17}$ But the problem of recruiting investors was a constant challenge not unique to Devonport, and the Herald had noted two months earlier a general reluctance by North Shore residents to invest in the tramway, "being desirous that the tramway should be constructed by Auckland speculative men, while they would enjoy the benefit and be absolved from the financial responsibility." 18

Following two weeks of public consultation, the orders were filed with the Waitemata County Council for final consideration. Nothing regarding the proposed sections was changed, but several additional important items were included relating to the tramway's operations. The orders revealed that trams would operate across standard-gauge $\left(4^{\prime} 8^{\prime} / 2^{\prime \prime}\right)$ forty pounds-per-yard steel Vignoles-style rails. These rails would be installed in the centre of the roads and at surface level in order to allow vehicles to run on either side of them. The plan for the route shows that the rails would be situated between wooden blocks set atop wooden sleepers with the gap between rails metalled in order to maintain a flat surface. Passing places were to be located at the end of each section, on Beach Road across from Duders Avenue in Devonport, and at the future site of Takapuna Grammar School, which marked the midpoint of section $2 .{ }^{19}$ Although the tram was allowed to operate using either horsepower or quiet mechanical power, it chose to follow the trend of most of the other domestic tramways and rely on horses. The company was also obligated to keep the roads and its own trackage and plant in good repair. 
The order outlined daily operations of the line, as well. The speed limit was set at three to ten miles per hour. Its standard hours of operation were from 7 a.m. to 7 p.m., except Sundays. The initial fares were set at:

Within standard hours:

Adults travelling within two miles: $3 \mathrm{~d}$

Adults travelling more than two miles: $1 \mathrm{~s}$

Outside of standard hours:

Adults travelling within two miles: $6 \mathrm{~d}$

Adults travelling more than two miles: $2 \mathrm{~s}$

Child rates:

Under 3 years old within two miles: free

Under 3 years old more than two miles: half price

Infants in arms: free

The tramway was not only intended for passenger service but was permitted to act as a goods carrier as well. A single piece of luggage of up to 14 pounds was free of charge, but additional parcels were charged according to their weight, with parcels of up to 200 pounds costing $2 \mathrm{~s} 6 \mathrm{~d}$. Perhaps reflecting some of the industries operating in the area, special rules were in place for bulk goods such as sugar, coffee, and grains.

The county council imposed additional conditions during its meeting at the end of November. It ruled that the company was responsible for widening roads so that 12 feet of right of way was free of obstruction on either side of the rails. In addition, the council was indemnified of all liability relating to roadworks, maintenance, or delays related to the tramway's construction or operation. It also insisted that the road be maintained for the duration of the contract, which was to last twenty-one years from the date the order was approved. ${ }^{20}$ The company was given six months to construct sections 1 through 4, while section 5 had to be completed within three years. Any violation of these conditions could lead to forfeiture of the franchise.

While the company was finalising its paperwork, the Cousins and Atkin Carriage Factory began assembling the first two pieces of rolling stock for the tramway. ${ }^{21}$ The company had ordered two open summer cars featuring back-to-back seating, with a narrow passageway down the centre. ${ }^{22}$ Horses could be attached to either end, eliminating the need for turntables or wyes along the line. In a letter to the Star, the writer revealed that "the whole of the material used [was] made in the city - wheels, axles, boxes, springs, bells, \&c., the only foreign material being the curtains of American duck, and although these cars are not so elaborately got up as the American ones, they have been built in two months, and at something like one third the cost of the imported article." 23 The Herald added that in "the cars, which are novel in construction, we particularly notice the arrangement of springs, by which the objectionable height of the general open car platforms is obviated. They are well built and handsome in appearance." 24 It later argued that, "though not so elaborate in construction, they are fully strong enough, and excellently adapted for their present purpose." ${ }^{25}$ The Star largely agreed but was critical of the lack of glass windows, stating that "this must, we think, be regarded as a serious defect." Nonetheless, they extolled the virtue of the tramcars: "in every respect they are a credit to the makers, and prove that our Auckland builders are not mere imitators, but can adapt their work to the requirements of the trade, and the pockets of their customers." 26 The Herald estimated that the two cars plus other equipment cost $£ 2,300$ in total. ${ }^{27}$ The first pair of cars was sent to Devonport on 29 April $1886 .{ }^{28}$ Once the initial line was constructed, the 
company also hoped to order two double-decker horse buses similar but stylistically distinct from those used in Auckland. ${ }^{29}$

The company did not wait for the paperwork to arrive before it began soliciting contractors to build the first section. By 8 January 1886, seven firms had offered to build it, with offers as high as $£ 400$ and as low as $£ 153$, several of which were made by members of the company’s board of directors. In the end, Bolton and Walsh's bid of $£ 248$ was selected. ${ }^{30}$ The company purchased from the government sixty-five tons of forty-eight pound rail to be used on the line, which was delivered in late $1885 .{ }^{31}$ The deed of consent by the Waitemata County Council was signed on 2 December 1885, and that of the Devonport Road Board on 11 January $1886 .{ }^{32}$ Construction was set to begin on 21 January, but all of this preparation was for naught. ${ }^{33}$ Due to an oversight, the company had failed to receive permission to build from the GovernorGeneral, without which it was unable to begin work. ${ }^{34}$ The Star playfully noted that "progress of the Devonport tramway has been delayed by the herculean exertions of the Red Tape and Circumlocution Office. "How not to do it." An Order-in-Council, which should have been gazetted weeks ago, has not yet been published. Oh, those overworked Tite Barnacles!" 35 When the order finally arrived on 26 March, Bolton and Walsh lost no time breaking ground. ${ }^{36}$ Within a week, construction crews were "making good headway" and there was optimism that the route would be completed by Easter: 25 April. ${ }^{37}$ But this date came and went and the prospects for a profitable year were low. ${ }^{38}$

The tramway company continued with its plans and published a request for tenders to build stables and a tram shed on 19 April. ${ }^{39}$ Construction must have proceeded soon after since nothing more is mentioned of them at this time. Several months later, a pair of reports revealed that a siding was installed near Cheltenham Beach to provide access to the shed and stables buildings, which were located on William Street (Eton Avenue). ${ }^{40}$ The spur broke off from the main line at Tainui Road and continued for a block until crossing William Street and passing into the company's property. The stable building and presumably tramcar repair shop was a two-storey barn-like structure that likely had two pairs of tracks that terminated within it. The Herald described it in 1886 as "a commodious and convenient structure, excellently adapted for the comfort of the horses and the convenience of the traffic." 41 A longer spur continued past the stables and ended in a shed situated near the Devonport Domain bowling lawn. Photographs from the late 1890s show this building as a canvas-covered, barrel-roofed structure with enough space to enclose the company's two tramcars.

The matter of installing a ticket office and passenger waiting room at Victoria Wharf was problematic. Cave petitioned the Auckland Harbour Board on 20 April for permission to erect a small structure at the foot of the wharf just above the high-water mark. The board granted the request with certain conditions, but at the next meeting on 4 May the petition was denied and referred to the Devonport Road Board. ${ }^{42}$ At what proved to be the final meeting of that board on 10 May, the group also denied the petition, referring the matter to the incoming Devonport Borough Council, which was replacing the road board. ${ }^{43}$ The new council did not meet until 14 June and discussion regarding the ticket office did not appear on the agenda. ${ }^{44}$ Documentary and photographic evidence suggests that no such structure was ever erected and that tickets were purchased directly from the conductor on the tramcar.

Bolton and Walsh were given thirty days to complete Section 1, but they ran two months behind schedule and were not actually finished until 8 July. ${ }^{45}$ Several events transpired to delay it. ${ }^{46}$ 
One of the workers, Thomas White, stated that they "found holes in the Cheltenham Road portion of the line. ... In the cutting there seemed to be an insufficiency of ballast." Another worker, Martin Brown, explained that "[s]everal alterations and changes were made by the order of Mr. Knox; in fact progress could not be made on account of them, the line had to be lifted on account of alterations in the levels." In addition, locals refused to remain off the track while it was under construction and even omnibuses drove directly over the track. ${ }^{47}$ The solution to these problems was to shift the entire right of way from the centre of the road to the edge along Pilot (Torpedo) Bay and on the south side of Cheltenham Road. This also allowed contractors to widen the radius of the curve at Beach and Cheltenham Roads, which had been too sharp for the tramcars to turn effectively. ${ }^{48}$ But doing this delayed the opening of the line by months and the right of way was not inspected until 13 July. Inspector Laurence Bourke granted a certificate of completion on 19 July but work crews spent an additional month improving the route. ${ }^{49}$ Because of this and the continuing poor weather, the opening of the line was postponed until late September.

Other issues also vexed the company. A collision between the tramcars on 21 June injured four people. ${ }^{50}$ Meanwhile, in early July, Ashley J. Hunter, a civil engineer who had been hired in 1885 to assist in surveying the route for the tramway, sued Knox, claiming that he had not received adequate compensation for his services. Knox returned by stating that the survey Hunter produced was subpar. The judge sided with Knox. ${ }^{51}$ The following week, John Swinnerton, a local resident, complained to the Devonport Borough Council that the tramline encroached upon his property, which was located at the bottom of Grey (Mays) Street. ${ }^{52}$ Following consultation with the company, the council ruled that the line did not encroach and that the issue was actually irregular fencing in the area. ${ }^{53}$

\section{From Victoria Wharf to Cheltenham Beach}

News finally broke on 9 September 1886 that the Devonport and Lake Takapuna Tramway's section 1 was ready for passengers. The Herald reported that "Mr. Hales, district engineer, has inspected the line, passed it, and the necessary permit has been obtained from Wellington." Hopes were high that the new line would be well-used and that construction on the second section, which had morphed into a new alignment that merged parts of sections 3 and 5, would begin soon. ${ }^{54}$ Two days later, the newspaper summarised that the "stabling is all in readiness, the horses for the working of the line purchased, and the preliminary details arranged." In the same article, it was announced that the tramway planned to commence formal operations on Monday, 20 September. ${ }^{55}$

In anticipation of its opening, the tramway company belatedly issued a press release outlining its twenty-one bylaws. ${ }^{56}$ The rules reflected the standards of a moral society by prohibiting smoking and intoxication and banning obscene or offensive language while within the confines of a tramcar. The company also prohibited staff from receiving gratuities, outlawed the playing of any musical instrument, banned dogs and other animals, and disallowed passengers from travelling on steps or leaning on railings, despite these being common practices elsewhere. Ultimately, the bylaws suggest a desire for the tramway to be upheld as a paragon of civilisation and high society. As such, blue collar workers were effectively banned since passengers wearing stained or soiled clothing or openly carrying trade tools were only allowed on board with the permission of the conductor. And the consequences for breaking these rules were harsh. Violators were given a fine of up to 40 s per offence, and if conductors failed to enforce the rules, they were liable for the same fine. ${ }^{57}$ 
The commencement of operations did not in fact occur until Saturday, 25 September, with a large press gathering and social event attended by most of the Devonport elite. The Herald reflected:

The weather was fine and very favourable for the enjoyment and success of the opening ceremony. On reaching Devonport, the party at once proceeded to the tram line, where the two vehicles of the company were awaiting their arrival, and in one of these, drawn by two excellent horses, the company traversed the whole length of the line to Cheltenham Beach, the distance being between a mile and a mile and a quarter, which was expeditiously gone over, including two short stays at points on the route, which have been arranged to be regular stopping places. ... The line is level for nearly the whole distance, the only exception being a short bit, which is at a very easy gradient, and judging from the smoothness and ease with which the cars traversed the distance the road has been thoroughly well laid down. ... On reaching Cheltenham Beach the company alighted, and proceeded to inspect the new stables, and afterwards partook of refreshment.

While the Herald focused on the tramway and its novelty, the Star described the accompanying festivities. Graves Aickin declared that, "although the times were very dull, there was good reason to hope for the future success of their undertaking, for as North Shore was one of the most beautiful localities around the city, there was sure to be an increase of population there, if anywhere." It was a bold prediction that foresaw a future that was still seventy years away. Other local businessmen made their own predictions and salutations. The day concluded with a return journey to Victoria Wharf via the tramway. ${ }^{58}$

The company soon took out a weekly advertisement in the Herald outlining its prices and timetable, which was coordinated with the Devonport Steam Ferry Company's ferry schedule. Discounts were given for tickets purchased by the dozen and special rates were available to schoolchildren. ${ }^{59}$ The route had one stop at the 0.3 mile mark, at Church Street in front of the Devonport Wharf and across from the recently opened Glen Arms Restaurant. ${ }^{60}$ Its second stop is not known with certainty but was likely at the 0.6 mile mark near the bottom of Jubilee Road, where the tramway could cater to the North Head community and the Devonport Domain. Reports of traffic for late spring 1886 were good, considering consistently poor weather conditions. The Herald reported: "We are glad to learn that the traffic on the Devonport tramway recently opened is quite as great as the promoters anticipated till the summer weather fairly sets in." 61 Three weeks later, it explained that "traffic is very fair, considering that the weather is still unsettled, and consequently Aucklanders are not tempted to resort to the North Shore for an outing." 62 Nonetheless, signs of future trouble were already apparent.

In late November, the company lowered two of its fares, with the price for children reduced to $1 \mathrm{~d}$ for the entire stretch from Victoria Wharf to Cheltenham Beach and the fare for adults from Victoria Wharf to Church Street reduced to the same price. The newspaper predicted that "[t]his liberal action on the part of the company cannot fail to promote tramway traffic, and to induce pleasure seekers to resort to the North Shore for a cheap day's outing." ${ }^{3}$ The lowered fares led to an immediate increase in passenger traffic, prompting the company to reduce its remaining fares from $6 \mathrm{~d}$ to $4 \mathrm{~d}$ for roundtrip adult tickets to Cheltenham Beach. This change was made "in the confident hope that their endeavours to cheapen the rates of travel will ensure the company increased patronage." 64 The timing was perfect for capitalising on New Year's traffic, which saw an increase in ferry and tramway traffic to Devonport. ${ }^{65}$ But this proved to be the crest of a wave. 
Beginning in early November, lawsuits involving the tramway became a monthly occurrence, damaging the company's reputation and emptying its pocketbooks. The first, brought to court by the contractor, claimed that the tramway had not paid for work done outside the parameters of their agreement, namely the three months of additional construction required to upgrade the Cheltenham Road trackage. The court ruled in the tramway's favour and made the plaintiff pay the defendant's court costs. ${ }^{66}$ The company won a second case in December against the owner of the Flagstaff Hotel, Michael Corcoran, who had failed to pay the agreed amount for his shares. ${ }^{67}$ Another suit was filed in January 1887 by J. J. Craig for non-payment of horses supplied for the trams, resulting in a fine for the company of $£ 45$, plus $£ 416 \mathrm{~s}$ in court costs. ${ }^{6}$ And in early February, the court ruled in favour of the New Zealand Timber Company, which had sued the tram company for $£ 414 \mathrm{~s} 6 \mathrm{~d}$, presumably for non-payment of timber used for sleepers and other wood structures. ${ }^{69}$ Whether the company ever paid these outstanding fines is unknown. However, the tramway itself appears to have continued to operate with its schedule appearing regularly in the Herald throughout these months.

None of these lawsuits or, indeed, a lack of passengers appears to have led directly to the company's collapse. Instead, it was caused by the technicality of the company failing to appoint a public officer for the year 1886, which was a requirement according to the Property Assessment Act of $1885 .^{70}$ The act declared that "[e]very company carrying on business in New Zealand shall at all times be represented by a person residing in the colony." That person had to be appointed within three months of the commencement of business and, failing that, the company "shall be liable to a penalty not exceeding fifty pounds a day for every day after the time aforesaid during which such neglect shall continue." ${ }^{.71}$ It is not clear which date should be used for calculating the commencement of business, but if the Deed of Consent by the Waitemata County Council on 2 December 1885 is used, then the company was liable for approximately ten months of fines, or $£ 15,000$. Considering the company was only formed with a capital investment of $£ 10,000$ and the tramway had failed to turn a profit since its opening, this amount was clearly impossible to pay. In the end, the company was only fined $£ 5$ plus court costs, but this was most likely only half of an arrangement with the judge. ${ }^{72}$ Six days after the court ruling, on 8 February, Justice Dudley Ward consented to what was certainly a prearranged request by three of the firm's principal creditors, Arthur Charles Atkin, William Atkin, and Adam Porter, for the company to be wound up. ${ }^{73}$ The tramway had operated for less than five months.

The news of the dissolution quickly spread throughout New Zealand, hitting newspapers as far afield as Dunedin. ${ }^{74}$ The last advertisement in the newspaper appeared on 10 February, although it is unclear when the trams actually stopped running. ${ }^{75}$ Justice Ward appointed Porter and William Buddle, the latter a director of the company, as provisional liquidators of the company's assets. ${ }^{76}$ Creditors were advised to submit their outstanding claims to Porter at his office on Elliott Street. ${ }^{77}$ Meanwhile, the company's property was put up for sale. ${ }^{78}$ The winning tender, decided at a public meeting on $28 \mathrm{March}$, went to Robert and Richard Duder, who offered $£ 650$ for the tramway infrastructure, its council franchise, and its plant. ${ }^{79}$ Justice Ward, meanwhile, set 15 April as the settlement date for creditors with outstanding claims. ${ }^{80}$ Although notices were posted in the Herald and Star throughout the preceding fortnight, no creditor appeared on the day. ${ }^{81} \mathrm{~A}$ final call to raise funds to discharge liabilities was published in mid-June, after which point it appears the Devonport and Lake Takapuna Tramway Company ceased to exist. ${ }^{82}$ 


\section{The Duder Brothers Take Charge}

The Duders are arguably the oldest European family in Devonport. Their patriarch, Thomas Duder, settled there in 1842 to serve as signal keeper of the Mount Victoria flagstaff. He and his wife, Margaret Dunne, had eight children, and the family quickly began acquiring land throughout the North Shore. Their two primary areas of settlement were along the waterfront of Pilot Bay and on a hundred acre tract beside Ngataringa Bay. Thomas focused much of his efforts on developing the area at the bottom of Church Street, which took on the name Devonport after his ancestral home in Devonshire, England. He invested heavily in infrastructure, notably in the erection of Devonport Wharf in 1866, which quickly became known as Duder's Wharf, since he was obliged to pay $£ 400$ toward its construction. ${ }^{83}$ The small boat-building and ranching community he helped develop along Church Street and Vauxhall Road served as the heart of Devonport for nearly two decades. ${ }^{84}$

Of Thomas Duder's children, his identical twin sons Richard and Robert were the most entrepreneurial, and had their hands in several industries. In 1870, at the age of nineteen, they established a mercantile store and land agent office at the bottom of Church Street across from the wharf. ${ }^{85}$ This is likely why Robert Duder later became a provisional director of the Devonport and Lake Takapuna Tramway Company in August 1885, since it had the potential to advance his real estate interests. ${ }^{86}$ However, the reason why the brothers purchased the line in 1887 is less clear. In subsequent years, the Duders used their wealth and influence to build much of the borough's drainage systems and roadways, using material that they imported or produced at the brickworks they founded beside Ngataringa Bay. They also competed in local commercial and industrial transport, primarily transporting goods rather than people. ${ }^{87}$ They may have hoped to use the tramway as an industrial carrier, since the franchise rights included goods haulage as far north as Lake Pupuke and throughout the Borough of Devonport.

Almost nothing is known about the daily operations of the tramway once it passed into the hands of the Duder Brothers. The brothers struggled at first to secure the franchise, facing conditions from the Devonport Borough Council that meant a more hands-on approach than they likely anticipated. When they first proposed buying the tramway, the Legal and Finance Committee cautioned that "before entertaining any request for consent to transfer the line must be put in good order," adding that the council "will agree to the suspension of traffic for a time to permit this being done." 88 It was surely a blow for the brothers, who probably hoped to secure the tramway's public transportation franchise without actually using it to transport people. The purchase was finalised on 13 June, but the brothers did not resume service at this time. ${ }^{89}$ The tram horses were sent out to graze on Browns Island for the winter, and likely did not return until October or November. ${ }^{90}$ The only evidence that service did resume comes through a letter to the harbour board published in the Herald in December, complaining that on three occasions, poor ferry service had led to the writer missing his connection with the tram. ${ }^{91}$

The Duders ran trams until late June 1888 when they petitioned the borough council to suspend traffic for the winter months in exchange for a promise to maintain the relevant roads throughout this period..$^{92}$ Although the request was reasonable and had precedent, allowing it led to a permanent discontinuance of service, something the brothers undoubtedly intended all along. A summary of a Devonport Borough Council meeting in July revealed some of the politics occurring behind the scenes. In it, the council chairman stated that "the consent to discontinue the service was conditional upon certain terms. These terms had not yet been complied with. It would be known that the Council had power to determine the contract at any 
time, as the original company had ceased to exist." Robert Duder replied in ignorance, claiming that "he did not understand that they were to put the road in good order before they ceased running the trams." This suggests that the Duder Brothers had not actively maintained the public roads through which the tramway passed since acquiring the line the previous year. ${ }^{93}$ What was more revealing in the report, however, was that there were only two regular passengers who used the line, including the individual who made the initial complaint. Duder explained that the problems with the tramway were exacerbated by members of the public who "did considerable injury to the tram lines by using it instead of using the other side of the road." Mayor Ewen Alison accepted that "the service was at present a loss" and added that "he scarcely thought they ought to insist upon any hard and fast line, or do any injustice just because it inconvenienced a few persons. Mr. Burgess said if the trams ceased 'buses would probably run." Nonetheless, there was an impasse between the Duders and the council since each was waiting for the other to repair their portions of the roads before the other would act. ${ }^{94}$ Several councillors had deduced that the Duders were unwilling to maintain the tramway at any cost, and Alison pushed for a new contract to ensure that the brothers complied with the council's requirement to maintain the roads. He set 9 November 1888 as the date that all repairs needed to be completed and tram service resumed if they wished to retain their franchise. ${ }^{95}$ Yet when that date came, the roads were not repaired, tram service had not resumed, and the matter did not arise at the following borough council meeting.

It was not until April 1889 that the matter of the tramway arose again at a council meeting, but it took another six weeks for any action to be taken by the Finance and Legal Committee, which recommended that the Duder Brothers have their franchise revoked for failing to fulfil the agreement of the previous July. ${ }^{96}$ But the Duders struck back by asking the council to allow them to suspend the line for two additional years in exchange for a pledge to expand the network by spring 1891. If such was not possible or viable, they agreed to remove the tracks by the end of April 1892. ${ }^{97}$ The council agreed to the suspension so long as the roads and tramway were maintained throughout the period to the satisfaction of the Foreman of Works. However, the council deferred any decision regarding abandonment of the tramway until such a time that a decision was necessary. ${ }^{98}$ Once more, the council outmanoeuvred the Duder Brothers, who were told to maintain the roads and tramway and not allowed to give up the franchise.

Nevertheless, the condition of the tramway continued to deteriorate throughout the subsequent two years. A report in December 1889 noted that the "unsatisfactory position of the tramway demanded attention." Mayor Malcolm Niccol "was of opinion that it was hopeless to expect fulfilment of the conditions of the original agreement in the altered circumstances, and he would submit proposals for adjusting the matter on an equitable basis." 99 In November 1890, Niccol petitioned the Duder Brothers to reopen the line to traffic and repair the roads and tramway, but nothing came of it. ${ }^{100}$ The negotiated deadline for action came and went in spring 1891. Henry Brett noted of Devonport in his Auckland Almanac for 1893 that "there is a tramway line, but trams do not now run."101 Masefield and Company, which had cast the wheels for the tramway's cars in 1886, applied to the borough council to use the line to test an experimental new motor. The plan was endorsed on condition that the Duder Brothers agreed, but not another word was written about the plan in newspapers. ${ }^{102}$ The ball finally dropped in September 1894. Nearly three years after the agreement between the Duders and the council had expired, the Foreman of Works reported that the last stretch of roadway in Devonport requiring maintenance was Beach Road and that the tramway presented a significant obstacle 
to completing this task. The council accepted reality and "decided to request the owners to lift the rails and sleepers of the tramway and make good the roadway at an early date."103

Characteristically, the Duder brothers deflected their obligations. Upon being informed that they had forfeited their franchise and were required to remove the tracks, they attempted to pass responsibility back to the council, whom they told to remove the tracks themselves. Mayor Alison countered that "the owners of the line should contribute to the cost of the removal, and there should be a clear extinction of all rights in respect to the tramway." He forwarded the matter to the Finance and Legal Committee in order to estimate the costs of removal and road repair in expectation of delivering the bill to the Duder Brothers. ${ }^{104}$ However, following three weeks of negotiations, the Duders were freed of their responsibilities and the original deed of consent was requested from the government in order to terminate the tramway's franchise. ${ }^{105}$ The deed was signed on 19 December 1894, marking the official end of Devonport's only tramway. ${ }^{106}$

\section{Relics of Fabricated Memories}

With the company dissolved, all that was left to do was remove its stock and repair the public roads. Throughout December 1894, the rails and sleepers were pulled from the right of way. They were shipped out of Devonport by the end of the year. ${ }^{107}$ The rails eventually found their way to a new Mitchelson Timber Company mill near Aoroa south of Dargaville, where they were used on a kauri and kahikatea timber tramline. ${ }^{108}$ Along Beach Road in Devonport, the street was substantially widened to absorb the portions that had previously included the tramway. Eventually a pedestrian pathway along the waterfront occupied some of this space.

The fate of the two tramcars is less known. Initially, both cars were moved to the company's property on William Street. In an article by Rod Cornelius for The Devonport Flagstaff, it was revealed that Esma Griffith "used to play on the old tramcars that had been left on the spare sections next to their house." Evidence of this was provided via a photograph taken around 1906 showing two young children climbing on a simple tramcar with the front of another tramcar visible at left. ${ }^{109}$ The tramcar appears to be lacking its siding, which had probably been used for advertisements. The tramcar shed was removed by 1900, leaving the two tramcars exposed to the elements. The adjacent stable and maintenance building remained for another decade, at which time the property was redeveloped and the tramcars disappeared. A 1936 history booklet noted that the tramcars "remained in existence for many years as pathetic reminders of a scheme that no doubt brought to its promoters visions of wealth. They were bought, or otherwise acquired, by residents of Cheltenham, and were used as bathing sheds, greenhouses, and so forth." 110 Their final disposition remains a mystery.

Within a generation of the removal of the tracks, historians began to recall the horse tramway critically, simultaneously introducing errors into its history. Thomas Walsh in 1924 noted the existence of the ticket office at Victoria Wharf, which was likely never built, and also blamed the company's dissolution entirely on poor revenue rather than constant, expensive legal troubles. ${ }^{111}$ The 1936 booklet, meanwhile, implied that the system remained in continuous use until 1894. ${ }^{12}$ Paul Titchener subsequently replicated these errors in his popular articles in the North Shore Times Advertiser in the 1970s. Gael Ferguson's chapter in The Hundred of Devonport added the final piece of misinformation to the historiography by stating that the tramway tracks were made of wood despite multiple primary sources stating otherwise. ${ }^{113}$ Together, these errors, oversights, and implications have led to a distorted view of the shortlived tramway. 
No one can ever say that the Devonport and Lake Takapuna Tramway Company was a successful venture. The project languished for over a year due to legal technicalities, only to fail less than six months after the tramway was built for similar reasons. It was a victim of heavy-handed bureaucracy, rampant speculation, and entrepreneurial excess. When the Duder Brothers took over, they intentionally or unintentionally ran the remains of the company into the ground, failing to realise the dream or even recoup the costs of buying the plant. If anything, the biggest surprise in the history of the tramway is how long it took for the tracks to finally be removed. Nevertheless, the tramway was a pioneer in a time when Devonport was undergoing substantial change. During this period, the settlement transitioned from a highway district into a borough council, the centre of the town completed its migration from Church Street to Victoria Street, and the population of Devonport grew, albeit much more slowly than property investors had anticipated. Ultimately, the tramway reflected the optimism of the era and the aspirations of the people of the North Shore of Auckland for the region to be viewed as more than a rural settlement, but rather as a city in its own right.

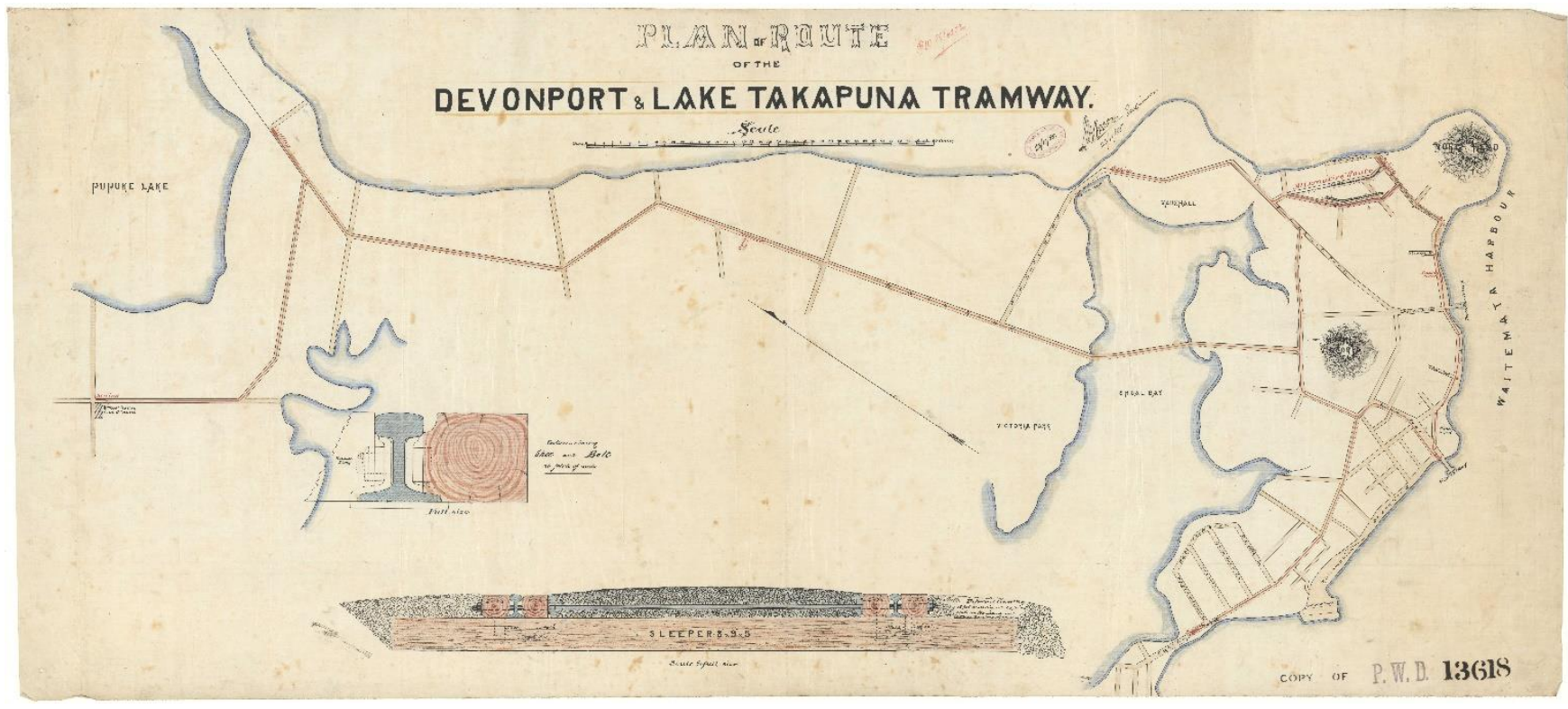

Figure 1. Plan of Route of the Devonport and Lake Takapuna Tramway, certified by James Knox, 23 November 1885. Courtesy Archives New Zealand, R19476029. 
${ }^{1}$ New Zealand Herald, 26 March 1886, 5.

${ }^{2}$ G. T. Bloomfield, "Urban Tramways in New Zealand 1862-1964," New Zealand Geographer 31, no. 2 (October 1975): 100.

3 "An Act to Facilitate the Construction and to Regulate the Working of Tramways," (21 October 1872), 36 VICT. 1872, No. 22, 71-102.

${ }^{4}$ Bloomfield, "Urban Tramways," 100.

${ }^{5}$ Bloomfield, "Urban Tramways," 100, 102-03.

${ }^{6}$ NZ Herald, 14 August 1885, 4.

${ }^{7}$ NZ Herald, 20 August 1885, 4.

${ }^{8}$ NZ Herald, 5 September 1885, 3.

${ }^{9}$ Auckland Star, 31 August 1885, 3.

${ }^{10}$ Auckland Star, 7 September 1885, 3; 17 September 1885, 3; 24 May 1886, 3; 12 November 1886, 3 ; and 29 December 1887, 1.

${ }^{11}$ NZ Herald, 5 September 1885, 3.

${ }^{12}$ NZ Herald, 3 October 1885, 6; Auckland Star, 3 October 1885, 8; Finance Committee minutes, County of Waitemata, 2 October 1885 (Auckland Archives).

${ }^{13}$ NZ Herald, 21 October 1885, 4.

${ }^{14}$ Auckland Star, 27 October 1885, 3.

${ }^{15}$ Auckland Star, 28 October 1885, 2.

${ }^{16}$ NZ Herald, 12 November 1885, 8; New Zealand Gazette 65 (19 November 1885), 1362.

${ }^{17}$ NZ Herald, 12 November 1885, 4.

${ }^{18}$ NZ Herald, 12 September 1885, 4.

${ }^{19}$ James Knox, "Plan of Route of the Devonport and Lake Takapuna Tramway," 23 November 1885 (Archives New Zealand R19476029).

${ }^{20}$ Auckland Star, 26 November 1885, 4.

${ }^{21}$ The Cyclopedia of New Zealand (Christchurch: Cyclopedia Company, 1902), 340.

${ }^{22}$ NZ Herald, 17 November 1885, 4.

${ }^{23}$ Auckland Star, 11 March 1886, 4.

${ }^{24}$ NZ Herald, 23 March 1886, 4.

${ }^{25}$ NZ Herald, 11 October 1886, 11.

${ }^{26}$ Auckland Star, 30 April 1886, 1.

${ }^{27}$ NZ Herald, 11 October 1886, 11.

${ }^{28}$ Auckland Star, 30 April 1886, 1.

${ }^{29}$ NZ Herald, 17 November 1885, 4.

${ }^{30} \mathrm{NZ}$ Herald, 16 January 1886, 4.

${ }^{31}$ Auckland Star, 8 January 1886, 2.

32 "Deed of Consent by the Chairman, Councillors, and Inhabitants of the County of Waitemata to the Devonport and Lake Takapuna Tramway Company, Limited," 2 December 1885, transc. John Webster (Special Collections, Auckland Libraries); "Deed of Consent by the Inhabitants of the Devonport Road District to the Devonport and Lake Takapuna Tramway Company, Limited," 11 January 1886 (Auckland Archives).

${ }^{33}$ NZ Herald, 16 January 1886, 4.

${ }^{34}$ NZ Herald, 3 February 1886, 4.

${ }^{35}$ Auckland Star, 3 February 1886, 2.

36 "Deed of Consent of the County of Waitemata." Order is appended to the end of the document.

${ }^{37}$ NZ Herald, 2 April 1886, 4.

${ }^{38}$ NZ Herald, 23 March 1886, 4; Auckland Star, 23 March 1886, 2.

${ }^{39}$ Auckland Star, 19 April 1886, 1.

${ }^{40}$ Auckland Star, 27 September 1886, 3. The structure occupied block 11, sections 47-49 and 63-64 of the Borough of Devonport.

${ }^{41}$ NZ Herald, 11 October 1886, 11.

${ }^{42}$ NZ Herald, 21 April 1886, 6; and 5 May 1886, 6.

${ }^{43}$ NZ Herald, 11 May 1886, 5.

Journal of New Zealand Studies NS32 (2021), 81-95 https://doi.org/10.26686/jnzs.iNS32.6865 
${ }^{44}$ Auckland Star, 15 June 1886, 4.

${ }^{45}$ NZ Herald, 9 July 1886, 4.

${ }^{46}$ NZ Herald, 4 May 1886, 4.

${ }^{47}$ NZ Herald, 12 November 1886, 3.

${ }^{48}$ Thomas Walsh, ed., An Illustrated Story of Devonport and the Old North Shore (Auckland: C. V.

Connolly, 1924), 22.

${ }^{49}$ NZ Herald, 12 November 1886, 3.

${ }^{50}$ Auckland Star, 22 June 1886, 3.

${ }^{51}$ NZ Herald, 2 July 1886, 2.

${ }^{52}$ NZ Herald, 13 July 1886, 6; "Borough of Devonport," 1889, Auckland Libraries Heritage

Collections, map 4233a; Devonport Borough Council 123, "Valuation Lists Index 1887-1898," item 2,30 .

${ }^{53}$ Auckland Star, 27 July 1886, 4.

${ }^{54}$ NZ Herald, 9 September 1886, 4.

${ }^{55} \mathrm{NZ}$ Herald, 11 September 1886, 4.

${ }^{56}$ New Zealand Gazette 54 (14 October 1886), 1324-25.

${ }^{57} \mathrm{NZ}$ Herald, 23 September 1886, 8.

${ }^{58}$ Auckland Star, 27 September 1886, 3.

${ }^{59} \mathrm{NZ}$ Herald, 30 October 1886, 4.

${ }^{60}$ Paul Titchener, Beginnings: A History of the North Shore of Auckland, 7 volumes (Bayswater, NZ:

Paul Titchener Publications, 1977-1984), volume 1, 41.

${ }^{61}$ NZ Herald, 7 October 1886, 4.

${ }^{62} \mathrm{NZ}$ Herald, 29 October 1886, 4.

${ }^{63} \mathrm{NZ}$ Herald, 26 November 1886, 5.

${ }^{64}$ NZ Herald, 9 December 1886, 4.

${ }^{65} \mathrm{NZ}$ Herald, 31 December 1886, 6.

${ }^{66}$ Auckland Star, 4 November 1886; NZ Herald, 12 November 1886, 3.

${ }^{67} \mathrm{NZ}$ Herald, 10 December 1886, 3.

${ }^{68}$ Auckland Star, 10 January 1887, 3; NZ Herald, 11 January 1887, 3.

${ }^{69}$ Auckland Star, 4 February 1887, 3.

${ }^{70}$ Auckland Star, 1 February 1887, 3; NZ Herald, 2 February 1887, 6.

71 "An Act to consolidate and amend the Laws regulating the Assessment of Real and Personal

Property for the Purposes of Taxation" (17 September 1885), 49 VICT. 1885 no. 41, 119.

${ }^{72}$ NZ Herald, 2 February 1887, 4.

${ }^{73}$ Auckland Star, 9 February 1887, 2; Auckland Star, 12 February 1887, 7.

${ }^{74}$ Christchurch Star, 10 February 1887, 4; Otago Daily Times, 10 February 1887, 2; Timaru Herald, 10 February 1887, 2; West Coast Times, 10 February 1887, 4.

${ }^{75}$ NZ Herald, 10 February 1887, 2.

${ }^{76}$ Auckland Star, 9 February 1887, 2; Auckland Star, 26 March 1887, 8.

${ }^{77}$ Auckland Star, 28 February 1887, 3.

${ }^{78}$ NZ Herald, 5 March 1887, 4.

${ }^{79}$ Auckland Star, 29 March 1887, 3.

${ }^{80}$ Auckland Star, 1 April 1887, 3.

${ }^{81}$ NZ Herald, 16 April 1887, 3.

${ }^{82}$ NZ Herald, 11 June 1887, 4.

${ }^{83}$ Humphrey Duder, "The Duders of Devonport," Journal of the Auckland-Waikato Historical Societies 20 (April 1972): 5-8; Walsh, An Illustrated Story of Devonport, 23.

${ }^{84}$ David Verran, The North Shore: An Illustrated History (Auckland: Random House New Zealand, 2010), 74.

${ }^{85}$ Marianne Philson, The Duder Family in New Zealand (Auckland: Bush Press, 1990), 76.

${ }^{86}$ NZ Herald, 14 August 1885, 4.

${ }^{87}$ Gael Ferguson, "Industry and Commerce," in The Hundred of Devonport: A Centennial History, ed. S. Musgrove, (Devonport, NZ: Devonport Borough Council, 1986), 55, 56, 58; Titchener, Beginnings, volume 3,11-12.

Journal of New Zealand Studies NS32 (2021), 81-95 https://doi.org/10.26686/jnzs.iNS32.6865 
${ }^{88}$ NZ Herald, 14 June 1887, 6.

${ }^{89}$ Minutes of the County of Waitemata, 1 July 1887, Auckland Archives.

${ }^{90}$ R. and R. Duder Cash Book, June 1887, John Webster Collection, Devonport Museum.

${ }^{91}$ NZ Herald, 30 December 1887, 5.

${ }^{92}$ Auckland Star, 26 June 1888, 8.

${ }^{93} \mathrm{NZ}$ Herald, 10 July $1888,6$.

${ }^{94} \mathrm{NZ}$ Herald, 10 July $1888,6$.

${ }^{95}$ Auckland Star, 10 July 1888, 3.

${ }^{96}$ NZ Herald, 2 April 1889, 6; NZ Herald, 16 April 1889, 6; NZ Herald, 30 April 1889, 6.

${ }^{97}$ NZ Herald, 14 May 1889, 6.

${ }^{98}$ Auckland Star, 28 May 1889, 2.

${ }^{99} \mathrm{NZ}$ Herald, 19 December 1889, 6.

${ }^{100}$ NZ Herald, 12 November 1890, 6.

${ }^{101}$ Henry Brett, Brett's Auckland Almanac, Provincial Handbook, and Strangers' Vade Mecum (Auckland: H. Brett, 1893).

${ }^{102}$ NZ Herald, 21 June 1893, 6.

${ }^{103}$ NZ Herald, 17 September 1894, 3.

${ }^{104}$ NZ Herald, 2 October 1894, 3.

${ }^{105}$ NZ Herald, 30 October 1894, 6.

106 "Deed of Consent of the Devonport Road District."

${ }^{107}$ NZ Herald, 20 December 1894, 6.

${ }^{108}$ Walsh, An Illustrated Story of Devonport, 22; Wayne Ryburn, Tall Spars, Steamers and Gum: A History of the Kaipara From Early European Settlement 1854-1947 (Auckland: Kaipara Publications, 1999), 67.

${ }^{109}$ Rod Cornelius, "Ramblings with Rod: New Information on Devonport Tramcars Unearthed," Devonport Flagstaff, 19 May 2006, 14-15.

${ }^{110}$ Souvenir Booklet Commemorating the Golden Jubilee of the Borough of Devonport Auckland N.Z. (Devonport: Borough Council, 1936), 38-40.

${ }^{111}$ Walsh, An Illustrated Story of Devonport, 22.

${ }^{112}$ Souvenir Booklet, 38-39.

${ }^{113}$ Ferguson, "Industry and Commerce," 55. 